\title{
REVITALISASI IDENTITAS AGAMA LOKAL UGAMO MALIM DALAM KEHIDUPAN MODERNITAS
}

\author{
Wensdy Tindaon
}

U niversitas Indonesia

\begin{abstract}
A bstract
The tide of the existence identity of Iocal religion in Indonesia is becoming an ongoing reality in Indonesian society. This situation is inseparable from social construction that misunderstand the faith practiced by local religion in Indonesia. In the understanding of Indonesian society, there is still a presumption that local religion are group of animist, primitive, conservative and godless. In this research, local religion give other perspective about local religion in modernity life. Local religion reconstructs their identity through a new identity that is more easily accepted by the state and society. The existence of local religion is also inseparable from a state that is still not able to provide equal are as citizens. This research focuses on identity of Ugamo Malim that have variety of dinamics and limitations such as others local religion in Indonesia. The experience of the loss and difficulty of maintaining a local religious identity in the past has provided awareness of state recognition. The state becomes a place as well as a guarantee for them in maintaining the continuity of their identity. The various negative stigma attached to local religion disappear as we seein the social lifeand religiousity of Ugamo Malim.Ugamo Malim who reconstructs their identity in modern life so that it has many similarities with the majority religion. The reconstruction of local religious identities is renewed to be relevant to modern life but without reducing the meaning of their identity.
\end{abstract}

Keywords: U gamo M alim, Identity. Reconstruction, modernity

\begin{abstract}
A bstraksi
Pasang surut eksistensi identitas agama lokal di Indonesia menjadi realitas yang masih berlangsung di masyarakat Indonesia. situasi ini tidak dapat dilepaskan dari konstruksi sosial atas kesalahpahaman tentang praktik kepercayaan dari agama lokal di Indonesia. Dalam pemahaman masyarakat Indonesia masih ada anggapan bahwa agama lokal sebagai kelompok animisme, primitif, konservatif dan tak bertuhan. Dalam penelitian ini, agama lokal memberikan suatu perspektif baru tentang agama lokal di kehidupan moderen. A gama lokal merekonstruksi identitasnya melalui identitas baru yang lebih mudah ditereeima oleh negara dan masyarakat mayoritas. Eksistensi
\end{abstract}


agama lokal juga tidak terlepas dari negara yang masih belum mampu memberikan hak yang sama sebagai warga negara. Penelitian ini fokus pada Ugamo Malim yang memiliki beragam dinamika dan hambatan di masyarakat Indonesia. Pengalaman atas kehilangan identitas dan sulitnya mempertahankan identitas Ugamo Malim menyadarkan mereka untuk mendapatkan pengakuan dari negara. Negara menjadi jaminan bagi mereka untuk dapat mempertahankan identitasnya. Beragam stigma negatif yang melekat pada Ugamo Malim di hilangkan saat melihat keseharian mereka dan praktik religiusnya di masyarakat. Identitas baru yang di bangun U gamo Malim memiliki persamaan dengan agama mayoritas di Indonesia. Rekonstruksi identitas religius dibarukan dan menjadi relevan dengan kehidupan moderen tanpa mengurangi makna identitasnya.

Kata-kata Kunci: Ugamo Malim, Identity, Reconstruction, Modernity

\section{PENDAHULUAN}

\section{A. Latar Belakang}

Isu agama merupakan salah satu isu yang hangat dan banyak di bahas di hampir seluruh belahan dunia termasuk Indonesia. Agama memberikan makna dan kedekatan batin bagi setiap manusia yang memilikinya sehingga menjadi jangkar (anchor) hidupnya. Agama tidak lagi hanya mengatur hubungan antara manusia dengan Tuhannya tetapi terdapat seperangkat nilai, ajaran, praktik hidup yang ditentukan oleh agama sehingga berimplikasi dalam kehidupan. Dalam artikel ini identitas agama dielaborasi di Indonesia karena terdapat dikotomi antara agama resmi dengan agama lokal. A pabila merujuk pada Undang-Undang yang telah di atur di Indonesia, maka pengakuan agama resmi dilakukan di masa orde baru. Pada masa orde baru agama resmi menurut Khotimah negara mengakui agama Hindu, Budha, Islam, Kristen Protestan dan Kristen Katolik. Setelah terjadi pergantian rezim Soeharto maka secara sah A bdurachman Wahid mengeluarkan KEPRES No 6 Tahun 2000. Keputusan ini menyatakan bahwa agama Konghucu diakui secara penuh di Indonesia dan menjadi agama resmi. Realitas pengakuan negara terhadap beberapa agama memberikan dilemma terhadap penganut agama lokal di Indonesia. Dilema ini merujuk kepada pengakuan negara terhadap identitas yang mereka miliki dalam masyarakat. N egara belum memberikan kesetaraan hak bagi agama lokal sebagai warga negara sehingga terjadi ketidakadilan dan eksklusi sosial di masyarakat. ${ }^{1}$

1 Khotimah, A gama dan civil society, dalam Jurnal Salahudin, 2014, hlm. 122. 
Dalam artikel ini penulis mengkaji eksistensi Ugamo Malim yang telah ada sejak sebelum negara Indonesia dibentuk. Ugamo Malim merupakan salah satu gerakan moral yang melakukan perlawanan terhadap kolonial Belanda. Perlawanan yang dilakukan oleh Ugamo Malim tidak terlepas dari terkikisnya kekuasaan Ugamo Malim di Tanah Batak. Kolonial Belanda tahu dan menyadari bahwa kekuasaan adat dan kepercayaan suku Batak terhadap adat sangat kuat sekali. Dalam memuluskan rencana untuk menguasai tanah Batak maka kolonial Belanda merusak kekuasaan tradisional dan kekuasaan adat suku Batak. Pada masa itu Sisingamangaraja orang paling berkuasa dan berpengaruh di tanah batak. Dalam penelitian dari Hirouse bahwa terjadi perang antara kolonial belanda dengan sisingamangaraja selama 30 tahun Iamanya. Kekalahan Sisingamangaraja bukan Iagi hanya karena kekalahan kekuatan senjata perang tetapi pengaruhnya sudah berkurang di tanah batak. Berkurangnyaa kekuatan dan pengaruh Sisingamangaraja tidak terlepas dari berpindahnya struktur kekuasaan kepada kolonial Belanda dan misionaris Kristen. Pada masa itu menurut Hirosue, Belanda secara sengaja menggandeng misionaris Kristen ke tanah Batak untuk memperlemah kekuasaan tradisional dan menggantinya menjadi kekuasaan Kristen. Secara perlahan konversi suku Batak menjadi Kristen terus berlangsung sampai Ugamo Malim menjadi minoritas di tanah Batak. ${ }^{2}$

Pada masa awal terbentuknya negara Indonesia salah satu momen besar yang dialami oleh Ugamo Malim atas kepergian kolonial dari tanah Batak. Kehadiran negara Indonesia dapat menyatukan dan mengikat beragam perbedaan identitas suku, agama, budaya dan ras dalam satu wilayah yang sama. Perkembangan agama-agama lokal di negara Indonesia di masa orde lama turut berimplikasi pada pendefinisian tentang agama di Indonesia. Definisi tentang agama bertujuan untuk menentukan ada kelompok yang beragama resmi dan kelompok aliran kepercayaan. $\mathrm{Hal}$ ini sesuai dengan penelitian dari Sukamto bahwa negara di tahun 1952 menyatakan bahwa agama harus memiliki syarat minimal berikut ini yaitu: memiliki kitab, Nabi, kepercayaan terhadap satu Tuhan dan pengakuan internasional ${ }^{3}$. Ketentuan negara ini secara implisit menyatakan bahwa keberadaan agama lokal menjadi kelas dua karena tidak setara dengan agama resmi. Syarat minimal yang ditentukan oleh

2 Hirosue, Masashi, Prophets A nda Follower In Batak M illennerian Responses To The Colonial O rder: Parmalim In N asiak Bagi A nda Parhudamdam 1890-1930, Australian National University, Canberra, 1988, hlm. 59.

3 Sukamto, Amos, Ketegangan A ntar Kelompok A gama Pada M asa O rde Lama Sampai A wal O rde Baru: D ari K onflik Perumusan Ideology N egara Sampai Konflik Fisik, Interuniversity InstituteOf Ecumenical And Misiological, 2013, hlm. 31. 
negara juga cenderung diskriminatif karena beberapa agama lokal menyampaikan bentuk ajaran bukan melalui tulisan tetapi hanya secara lisan. Kemudian ditambah dengan pengakuan internasional menyulitkan bagi agama lokal karena sifatnya yang kedaerahan. Realitas ini menyudutkan posisi agama lokal dalam kehidupan negara dan masyarakay di Indonesia. ${ }^{4}$

Dalam membatasi ruang gerak agama lokal di Indonesia maka negara membentuk Pengawas Aliran Kepercayaan Masyarakat (PAKEM). Pada A pril 1972 menurut Ariyono bahwa terdapat 217 airan kebatinan dan 427 cabang kebatinan di Indonesia. Perkembangan aliran agama lokal ini turut mempengaruhi politik nasional sehingga negara melalui beragam kebijakan mengintervensi agama lokal ${ }^{5}$. Salah satu bentuk intervensi negara dan masyarakat melalui pembubaran aliran kepercayaan di Indonesia. Keberadaan aliran kepercayaan dianggap meresahkan dan tidak sesuai dengan nilai-nilai yang dianut di masyarakat. Pembubaran negara terhadap aliran kepercayaan memiliki legitimasi kuat karena Pancasila berdasarkan ketuhanan yang maha esa. Pada masa itu stigma negatif yang melekat pada agama lokal adalah kel ompok tak bertuhan dan aliran sesat sehingga meresahkan masyarakat. Dalam memulihkan kewarganegaraan penganut aliran kepercayaan tadi maka negara mengaharuskan untuk berafiliasi dengan agama resmi di Indonesia. Agama lokal Towani Tolotang dalam penelitian dari Hasse, dipaksa negara berafiliasi dengan agama Hindu melalui Surat Dirjen Bimas Hindu Bali/ Budha No. 2/ 1966. Kenyatan ini memaksa penganut agama lokal untuk kehilangan identitas agama mereka dan menggantinya dengan identitas agama resmi. Padahal pada masyarakat Indonesia agama bukan hanya sekedar simbol yang ditempel pada KTP saja tetapi menjadi tuntunan hidup setiap individu. ${ }^{6}$

Memasuki masa reformasi maka serangkaian perubahan terjadi di hampir seluruh dimensi kehidupan kenegaraan maupun masyarakat Indonesia. Beberapa momentum dan keputusan yang signifikan terjadi terhadap keadilan bagi penganut agama lokal.Keberpihakan negara pada agama lokal ditandai oleh keputusan presiden Abdurachman Wahid terhadap agama Konghucu dan etnis Cina. Pada penelitian dari Mustajab menyatakan bahwa Abdurachman Wahid mencabut Instruksi Presiden No. 14/ 1967 dan mengeluarkan KEPRES No 6 Tahun 2000 sehingga

4 Ibid,.

5 Aryono, Pergulatan aliran kepercayaan dalam panggung politik Indonesia, 1950an-2010an: Romo semono sastrodihardjo dan aliran kapribaden. Jurnal sejarah Citra Lekha, 2018, hlm. 61.

6 Hasse, J, Kebijakan N egara terhadap A gama Lokal Towani Tolotang di Kabupaten Sidrep, Sulawesi Selatan, 2015, hlm. 158. 
agama Konghucu dan etnis Tionghoa dapat merayakan Imlek. Pada tahun 2006 dalam penelitian dari Aryono secara sah agama lokal di atur dalam UU No. 23/ 2006 mengenai administrasi kependudukan kemudian negara pada tahun 2007 mengeluarkan pelaksanaan UU Adminduk 2006 sehingga wajib dicatat dalam data based pemerintah. ${ }^{7}$ Perjuangan penganut agama lokal tidak lagi hanya pada KTP saja tetapi mulai menyadari pentingnya pendidikan bagi mereka. Dengan demikian di tahun 2016 dikeluarkan peraturan pemerintah pendidikan dan kebudyaan (PERMENDIKBUD) No. 27 Tahun 2016 tentang pelayanan pendidikan bagi penganut agama lokal. Wadah yang diberikan pada agama lokal melalui MLKI (Majelis Luhur Kepercayaan Ketuhanan Indonesia) dalam mempersiapkan kurikulum dan tenaga pengajar di sekolah. Keputusan terbaru tentang agama lokal didapatkan melalui Mahkamah Konstitusi tentang pengakuan negara terhadap agama lokal di KTP. Keputusan ini secara resmi memberikan legalitas secara hukum untuk mendapatkan hak kewarganegaraannya di Indonesia dan tidak dapat di intervensi secara tidak adil.

Penolakan terhadap agama lokal tidak terlepas dari label negatif yang melekat pada diri mereka di masyarakat. Pada penelitian dariAdams menyatakan bahwa agama lokal dianggap kelompok tak bertuhan dan sesat sehingga menimbulkan jarak sosial di masyarakat. ${ }^{8} \mathrm{H}$ al yang sama juga disampaikan oleh Harahap bahwa Ugamo Malim dianggap sebagai pemuja sipel ebegu ${ }^{9}$ (kepercayaan pada roh nenek moyang/ setan). Konstruksi pengetahuan masyarakat tentang penganut agama lokal yang tak bertuhan dan sesat memberikan dampak negatif yang besar. Rasa takut dan penolakan dapat muncul di masyarakat karena dengan menganut agama lokal dianggap telah melanggar nilai-nilai agama mayoritas. Pemahaman yang keliru tentang agama lokal ini secara sengaja dikonstruksi secara terus menerus dalam menekan keberadaan agama lokal di masyarakat. Kesulitan mengekspresikan identitas di masyarakat berujung pada terdekonstruksinya identitas agama lokal. Pada beberapa momen banyak penganut agama lokal telah meninggalkan identitasnya sehingga berdampak pada eksistensi kelompoknya. Di sisi lain negara juga belum mampu memberikan kesetaraan sebagai warga negara kepada penganut agama lokal. Dalam kehidupan masyarakat juga penganut agama lokal mengalami eksklusi sosial dan tinndakan diskriminatif oleh

7 Mustajab, Ali, Kebijakan Politik Gusdur Terhadao China Tionghoa D i Indonesia. Jurnal Agama Dan Hak Azasi Manusia, 2015, hlm. 158.

8 Adams, M Kathleen, The D iscourse of Souls Ia Tana Toraja (Indonesia): Indigineous N otions A nd Christian Conception, University Pitsburg, 1993, hlm. 123.

9 Sipelebegumerupakan istilah yang digunakan oleh Misionaris Kristen pada tanah Batak dalam mengidentifikasi kelompok atau individu yang menyembah roh maupun setan. 
negara maupun masyarakat. Kondisi ini menyulitkan penganut agama lokal dapat mempertahankan identitasnya di masyarakat. ${ }^{10}$

Pengalaman yang panjang dan keadaan menjadi minoritas menimbulkan suatu pandangan baru terhadap perubahan pada identitas agama lokal. Perubahan identitas dilakukan agar dapat menyesuaikan kondisi kehidupan modern dan proses penerimaan negara dan masyarakat terhadap kelompok agama lokal. Pada penelitian ini secara khusus mengelaborasi rekonstruksi identitas Ugamo Malim dalam kehidupan modernitas. A pabila terdahulu agama lokal diasosiasikan dengan kelompok konservatif, primitif dan menolak modernitas maka dapat dipatahkan oleh penganut Ugamo Malim. Ugamo Malim membalikkan anggapan umum itu dengan meleburkan diri dalam kehidupan modernitas. Sikap untuk menerima hal-hal baru dalam Ugamo Malim dilakukan dalam merekonstruksi idnetitasnya di masyarakat. Penganut Ugamo Malim sudah sul it dibedakan dalam kehidupan sehari-hari apabila hanya dilihat dari atribut pakaian maupun kehidupan sehari-harinya. Ugamo Malim secara konsep teologis juga memiliki banyak persamaan dengan agama resmi di Indonesia. Pada pergaulan dengan penganut agama lai nnya diikat melal ui persamaan yang telah dibangun. Konstruksi dalam persamaan nilai dan cara hidup ini membantu Ugamo Malim diterima dalam kehidupan masyarakat.

\section{B. Pertanyaan Eskplorasi}

1. Bagaimana cara Ugamo Malim merekonstruksi identitasnya dalam kehidupan modernitas?

2. Bagaimana kapasitas pemimpin Parmalim dalam melakukan perubahan identitas Ugamo Malim?

3. Mengapa Ugamo Malim masih dianggap sebagai aliran kepecaya?

\section{KONSEP TRADISI DAN IDENTITAS DALAM KEHIDUPAN UGAMO MALIM}

Tradisi dan agama lokal suatu kombinasi yang telah melekat lama sejak Indonesia masi h menjadi nusantara. Dua unsur ini dalam kehidupan modernitas terkadang dalam beberapa dimensi kehidupan sudah tidak relevan lagi diaplikasikan dalam hidup. Konsep tradisi dianggap sebagai sisa kebudayaan yang ada di masa lalu dan masih dipertahankan oleh

10 Harahap, Irwansyah, Rasionalisasi R eligius D alam D iskursus Keagamaan D i Indonesia Parmalim Batak Toba, 2000, hlm. 2014. 
kelompok tradisional yang ada di daerah tertentu. Cara memandang tradisi yang demikian mereduksi makna dan nilai yang terdapat dalam setiap tradisi yang telah ada. Tradisi dianggap sebagai sesuatu yang telah final dan tidak mengalami perubahan. Pada penelitian ini justru memberikan suatu cara pandang baru dengan melihat keunikan dan relvansinya pada dunia modern sekarang. Tradisi menurut Zheng, merupakan suatu tata cara baik berupa ingatan, nilai, moral, tata kelakuan, cara berpikir maupun berupa artefak yang masih dipertahankan dan dapat disesuaikan dengan jamannya ${ }^{11}$. Penekanan tradisi dapat menyesuaikan dengan jaman menunjukkan sifatnya tidak kaku tetapi mengalami perubahan. Demikian juga pada agama lokal yang ada di Indonesia dengan seperangkat nilai adat, tradisi dan nilai religiusitasnya justru dapat menyesuaikan dengan kehidupan modern. Tradisi terbentuk dari pengalaman bersama dan disepakati sebagai nilai dan dipraktikkan secara berulang-ulang sehingga menjadi tradisi. Dalam kehidupan modern sekarang juga berlaku hal yang sama saat masuk nilai baru maka menciptakan sikap dan cara pandang baru. Nilai baru belum tentu bertenntangan dengan nilai lama yang telah terdapat dalam tradisi agama lokal. Justru penerimaan nilai baru dilakukan melalui proses panjang dan penyesuaian dengan kebutuhan kelompok dan identitas baru mereka.

Dalam ruang kehidupan modern yang kita jalani sekarang tidak terlepas dari kehidupan di masa lalu dengan beragam perangkat tradisi dan nilainya yang masih kita gunakan. Kemampuan daya nal ar kita dapat menangkap nilai tradisi yang di wariskan oleh masa lalu masi h kita pakai dalammkehidupan sekarang. Bentuk pemeikiran, nilai masyarakat, agama dan seluruh benda fisik yang kita gunakan tidak muncul tiba-tiba tetapi bagian dari tradisi di masa lalu. Kehidupan masa lalu tidak dapat kita lepas secara paksa karena masih terhubung dengan dunia kita sekarang hidup. Dengan demikian, konsepsi tentang tradisi memiliki sifat kelenturan terhadap jamannya. Nilai dan maknanya bisa saja sama dari jaman dulu maupun dalam kehidupan modernitas tetapi cara penyampaian dan bentuknya yang berbeda. Bila mengelaborasi tentang tradisi maka dapat menemukan suatu keagungan di masa lalu yang dapat dibanggakan sebagai identitas kelompok. Tradisi juga menjadi realitas kekayaan nilai dan tahap kemajuan yang pernah dialami oleh suatu masyarakat tertentu. Belajar tentang tradisi dapat mendewasakan pemikiran kita bahwa kesalahan di masa lalu jangan sampai terulang. Begitu juga kemampuan yang telah dimiliki di masa lalu dapat direvitalisasi kembali dalam mengembangkan tradisi baru saat ini.

11 Zheng, Hangsheng, O n M odernity Changes to Tradition: A Sociological Perspective, Wesleyan University, 2012, hlm. 105. 
Dalam penelitian ini melakukaan suatu kajian ulang tentang tradisi dan identitas pada agama lokal di Indonesia. A pabila kita terjebak pada konsep tradisi yang tradisional, kaku dan tidak mengalami perubahan maka sebenarnya kita yang masih primitif. Pemahaman masyarakat secara umum terhadap agama lokal yang dianggap tak bertuhan, aliran sesat dan primitif sudah kurang relevan. Pemahaman ini muncul diakibatkan egoisme dan ketidakmampuan menerima pengetahuan baru tentang agama lokal. Kedekatan antara agama lokal dengan tradisi dan adat tidak dapat dipungkiri menjadi realitas yang ada. Namun, konstruksi pengetahuan tentang agama lokal masih dihegemoni oleh pandangan subjektif yang menyudutkan penganut agama lokal tanpa diimbangi oleh data yang valid. Pada penelitian ini mengangkat isu Ugamo Malim dalam menerapkan nilai tradisionalitasnya dalam kehidupan modern. Bila sebelumnya agama lokal di anggap tradisional, konservatif dan pemuja roh nenek moyang maka dapat dibahtah oleh Ugamo Malim. Ugamo Malim secara kehidupan sehari-hari sangat dekaat dengan kehidupan modern. Konsep ketuhanan yang mereka miliki hampir sama dengan agama resmi lainnya di Indonesia. Rasionalitas dan cara berpikir mereka juga sama dengan masyarakat lainnya. Bahkan kepercayaan pada kekuatan gaib dan mistis sudah lama ditinggalkan karena bertentangan dengan nilai agama yang mereka miliki. Hal ini tentu menjadi mengaburkan definisi tentang agama dan kepercayaan karena tidak terdapat batas yang jelas memisahkan antara keduanya.

Identitas yang melekat dalam tradisi agama lokal dapat saling mengisi dalam kehidupan modern. Tradisi menjadi identitas yang otentik yang dimiliki oleh penagnut agama lokal di Indonesia. Tradisi agama lokal dengan serangkaian atribut agama, cara ibadah, praktik ritual maupun sikap hidup telah menjadi identitas yang dimiliki secara bersama bagi kelompok mereka. Namun, saat berhadapan dengan masyarakat luar yang juga memiliki tradisi agama yang berbeda maka tidak harus diukur dengan ukurannya. Begitu juga dengan Ugamo Malim yang pada masa dulu begitu kental dengan pakaian tradisional batak, tertutup dan menolak modernitas. Cara praktik hidup demikian dianggap sudah tidak relevan untuk dipertahankan oleh Ugamo Malim. Para pemimpin Ugamo Malim berusaha memberikan suatu ruang perubahan pada diri mereka agar dapat lebih diterima di masyarakat. Perubahan diwujudkan dalam bentuk keseharian mereka dengan menerima kehidupan modernitas dan penggunaan alat teknologi dan internet. Suatu hal yan sulit bila hanya mengidentifikasi mereka melalui kehidupan sehari-hari maupun praktik hidupnya. Pandangan bahwa agama lokal sebagai kelompok tradisional dan tidak modern sudah kurang relevan untuk sekarang.

Secara lebih Ianjut identitas menurut Bikhu adalah suatu hubungan yang menekankan pada kedaulatan (sovereignity) wilayah, makna, atribut 
dalam ruang yang legal dan diabstraksikan dari hubungan sosial, ekonomi dan politik sehingga memiliki otentisitas yang membedakannya dengan kelompok lainnya yang berbeda. ${ }^{12}$ Keunikan identitas yang dimiliki oleh Ugamo Malim tentu memberikan suatu makna tersendiri bagi kelompok mereka. Makna ini diinternalisasi dalam diri setiap individu dalam kelompok sehingga melekat dan tidak terpisah dari diri individu. Lebih lanjut lagi Bikhu menjelaskan tiga tahapan identitas pada diri individu.

Pertama, setiap individu memiliki keunikan secara individu baik dalam fisik, biografi, pengalaman hidup maupun nilai dominan dalam hidupnya. Kedua, tidak Iagi hanya pada tataran individu saja tetapi mengikat secara identitas kelompok. Setiap individu terikat pada keanggotaan berdasarkan tempat tinggal, etnik, agama, budaya maupun hobi sehingga membedakannya dengan individu lain. Ketiga, identitas meletakkan manusia menjadi memiliki makna sebagai human beings (manusia seutuhnya). Pada tahapan ini manusia melalui serangkaian identitas yang melekat dalam dirinya dapat memberikan dirinya sebagai human beings. ${ }^{13}$

Kemampuan manusia sebagai human beings ditunjukkan dengan caranya bersikap, berpikir dan menuntunnya dalam kehidupan bermasyarakat. Pada tahap inilah fungsi identitas sebagai Ugamo Malim sehingga dapat bertahan dengan beragam tindakan diskriminatif yang mereka alami.

\section{KAPASITAS PEMIMPIN UGAMO MALIM DALAM PERUBAHAN STRUKTUR}

Kemapanan secara struktur tradisional telah terbentuk dal am Ugamo Malim sejak suku Batak masih menganut kepercayaan tradisional. Struktur tradisional ini masih dipertahankan dan dilanggengkan dalam kehidupan modern Ugamo Malim sekarang. Terdapat perbedaan antara suku Batak yang menganut agama Kristen maupun Islam dengan suku Batak penganut Ugamo Malim. Irisan perbedaannya cukup tipis terletak pada sistem dan struktur adat yang dimilikinya. Pada suku Batak yang beragama Kristen maupun Islam menganut prinsip dalihan $\mathrm{Na}$ tolu yaitu elek marboru (mengayomi saudara perempuan kita dan marga suaminya, manat mardongan tubu (bersikap hati-hati dan bijak pada keluarga satu marga) dan sangap marhula-hula (hormat kepada pihak keluarga lakilaki dari istri). Kemudian struktur tradisional adat ini juga dimiliki oleh

12 Bikhu Parekh, A. N ew Politics of I dentity: Political Principlefor an Interdependen W orld, Plagrawe, Macmillan, 2008, hlm. 8

13 Ibid., 
penganut Ugamo Malim tetapi menambahkan satu unsur lagi yaitu hormat marraja (Sikap menghormati raja yang ada di sekitar kita). Konsep adat yang dipakai dalam Ugamo Malim yaitu suhi ampang naopat sehingga menegaskan perbedaan dengan penganut agama lainnya. Konsep hormat marraja ini yang tidak ada dalam Suku Batak yang beragama Kristen maupun Islam. Pada Penganut Ugamo Malim masih kental karena pengakuan terhadap Sisingamanagaraja dan pemimpin Ugamo Malim. Realitas ini menunjukkan sikap kepatuhan pada pemimpin mereka dalam kehidupan beragama maupun kehidupan sehari-hari.

Ugamo Malim memiliki pemimpin Ihutan yang memiliki wewenang yang kuat dan kharismatik baik dalam agama maupun kehidupan seharihari. Ihutan biasanya hanya bertugas di pusat saja dan menjalankan kewajiban pemimpin yang lebih luas. Namun, dalam setiap punguan (cabang) terdapat U lu Punguan (pimpinan cabang) yang mengatur dan melaksanakan tugas memimpin kegiatan ibadah maupun adat di wilayah mereka. Pengaruh yang dimiliki cukup kuat dan dipatuhi oleh para penganut Ugamo Malim. Ulu Punguan dianggap memiliki tingkat pengetahuan agama yang dalam sehingga menjadi teladan dalam bersikap, berpikir di kehidupan sehari-harinya. Power yang dimiliki oleh pemimpin Ugamo Malim memiliki keistimewaan dibandingkan dengan penganut biasa. Secara struktur menurut Loyaldengan kemampuan dan kapasitas pemimpin yang kuat dapat memungkinkan terjadinya perubahan pada struktur Ugamo Malim. Perubahan struktur tradisional Ugamo malim membantu dalam merekonstruksi identitasnya di dalam masyarakat. ${ }^{14}$ Perubahan diinisiasi oleh pemimpin Ugamo Malim melalui serangkaian ide dan pengalaman yang pernah dialami oleh kelompok mereka di masa lalu. Keistimewaan lain yang dimiliki oleh pemimpin Ugamo Malim yaitu akses terhadap resources (sumberdaya). Di dalam struktur tradisional Ugamo Malim terdapat suatu power yang dapat memberdayakan seluruh sumberdaya yang dimiliki oleh penganut Ugamo Malim.

Perubahan yang diinisiasai oleh pemimpin Ugamo Malim tidak dapat terwujud tanpa adanya kelengkapan skill and knowledged. Kapasitas pemimpin Ugamo Malim sangat memumpuni tentang pengetahuan agama serta cara kepemimpinannya di dalam kelompok. Menurut Giddens ${ }^{15}$ ) pemimpin dapat melakukan perubahan dengan sifat aktif dan otoritatif dalam struktur. Pengalaman memimpin dalam agama maupun kehidupan sehari-hari telah memberikan kesadaran bahwa ada hambatan

14 Loyal Steven, The Sociology of Giddens, Plutto Press, 2003, hlm. 80.

15 Giddens dalam Loyal, hlm. 51. 
yang mereka alami pada identitas lama yang mereka miliki. Dalam meminimalisir hambatan identitas lama ini maka dilakukan perubahan identitas baru. Perubahan menuju identitas baru tidak dapat dilakukan tanpa seijin pemimpin Ugamo Malim karena butuh penyesuaian dengan nilai keagamaan Ugamo Malim. Penyesuaian bertujuan agar penerimaan nilai-nilai baru pada Ugamo Malim tetap sejalan dengan nilai ajaran Ugamo Malim. Kapasitas untuk mengetahui nilai baru ini bertentangan atau tidaknya hanya dimiliki oleh Pemimpin Ugamo Malim. Dampak setiap perubahan tentu berimplikasi pada seluruh tata cara dan nilai kehidupan agama yang mereka miliki. Pemilihan nilai yang tepat untuk dirubah menjadi identitas baru menjadi beban dan tanggung jawab yang di emban oleh pemimpin Ugamo Malim. Selektif dalam memilih identitas yang tepat menjadi cara agar nilai religiusitas dan nilai tradisional Ugamo Malim tidak berkurang makna esensinya.

Pada tahapan skill dan konwledged sudah terpenuhi maka menimbulkan kesadaran diskursif bagi pemimpin Ugamo Malim. Pada tahapan kesadaran diskursif terdapat suatu sifat struktur yang enabling dan constraint. Pemimpin memiliki kesadaran bahwa di dalam struktur terdapat halangan (constraint) berupa kemapanan nilai adat, tradisi dan nilai agama yang dapat menghambat perubahan struktur. Nilai agama dan adat tentu sudah dipertahankan dan diakui oleh seluruh penganut Ugamo Malim sejak dari dulu. Kemapanan struktur tradisional ini berdampak pada sikap konservatif dan menolak perubahan pada identitas Ugamo Malim. Pada keadaan constraint lebih banyak di alami oleh penganut biasa Ugamo Malim karena diangap sebagai sesuatu yang benar dan final. Namun, terdapat suatu cara lain yang dimiliki Ugamo Malim agar dapat melakukan perubahan struktur mereka. Perubahan dapat dilakukan oleh Pemi mpin Ugamo Mal im dengan sifat struktur yang enabling (memungkinkan). Kemampuan enabling (memungkinkan) dalam struktur hanya dapat dilakukan apabila memiliki tingkat otoritas yang kuat dan memiliki akses di dalam struktur. Syarat melakukan enabling dalam struktur telah dipenuhi pemimpin Ugamo Malim dengan kepemimpinan yang otoritatif dan kharismatik. Selain itu, pemimpin Ugamo Malim memiliki kelebihan dalam skill dan knowledged tentang agama yang mereka anut. Secara kapasitas dapat menjelaskan fungsi dari setiap aturan dan nilai yang akan diubah sehingga melahirkan identitas baru bagi Ugamo Malim. Hal ini tidak dapat dilakukan oleh penganut Ugamo Malim biasa karena secara otoritas tidak ada dan kemampuan skill dan knowledged juga tidak terpenuhi. Keistimewaan ini yang dimanfaatkan oleh Ugamo Malim agar mereka memiliki identitas baru yang lebih diterima di masyarakat. 


\section{PARMALIN SEBAGAI AGAMA}

Salah satu keistimewaan Indonesia dibandingkan dengan negara lainnya di dunia terletak pada keragamannya. Di masyarakat Indonesia keragamam tidak hanya sebatas pandangan politik, ekonomi, sosial dan pendidikan saja. Indonesia memiliki perbedaan secara prinsipil dan nilai pegangan hidup yang terlihat dari latar belakang belakang identitas ras, suku, agama, dan kedaerahan. A pabila di bandingkan dengan negara dunia lainnya yang cenderung homogen dengan kesamaan ras, agama dan suku masih dapat timbul disintegrasi masyarakat. Indonesia telah berumur 73 tahun dan telah mampu bertahan dan menyatukan perbedaan identitas di masyarakat. Kemampuan ini tidak semua negara di dunia memilikinya dan kita patut bangga terhadap negara kita yang cukup berhasil sampai saat ini. Sikap dalam masyarakat multikulturaal menekankan pada pengakuan adanya perbedaan dan mengakui kebebasan bagi kelompok minoritas maupun minoritas untuk hidup berdampingan. Begitu juga dengan agama lokal yang ada di Indonesia memiliki kesempatan yang sama sebagai kelompok maupun individu untuk memiliki kebebasan dan diakui sebagai agama. Sikap penerimaan terhadap kelompok minoritas di Indonesia justru menunjukkan kemajuan peradaban dan kemtangan pemikiran masyarakat Indonesia dalam level dunia. Namun sikap penolakan terhadap keberadaan agama lokal menunjukkan kemunduran peradaban kita dan tidak pernah ingin menerima perubahan yang dapat terjadi di masyarakat.

Cara pandang kita dalam melihat identitas agama lokal dapat membantu mengintegrasikan seluruh unsur perbedaan di masyarakat. Sebagaimana masyarakat Indonesia, identitas keagamaan bukan hanya sebatas simbol yang tidak memiliki makna yang berarti. Dalam penelitian dari Kingdijelaskan identitas agama dan nilai spiritualitas menjadi sumber identitas yang dapat berkembang dalam setiap individu maupun kel ompok dalam kehidupan bermasyarakat. Begitu juga dengan identitas agama lokal yang melekat dalam diri mereka masing-masing menjadi tuntunan dan cara hidup (way of life) kehidupan mereka. Signifikansi identitas agama begitu besar dalam diri setiap hidup individu karena menjadi jangkar (anchor) yang meneguhkan pendirian mereka di masyarakat. Agama diwujudkan untuk menciptakan keteraturan sosial dan megisi kebutuhan batin yang dmiliki oleh setiap manusia dalam hidupnya. Kebutuhan agama suatu kelaziman dalam kehidupan modern dengan keterbatasan kemampuan nalar dan rasionalitas yang dimiliki oleh manusia. Modernitas menawarkan beragam pilihan yang terbatas, ketidakpastian dan kecemasan setiap harinya. Realitas demikian tidak dapat dihindari dalam kehdiupan modern sehingga dibutuhkan suatu hal yang dapat mengisi kekosongan itu. Agama melakukan kerjanya secara efektif dalam memberikan suatu yang tidak bisa dijangkau nalar 
pikiran manusia dan memberikan ketenangan batin setiap harinya. Dampak yang terjadi apabila identitas agama lokal di cabut begitu saja maka akan menimbulkan kekacauaan dalam individu maupun kelompok. Agama lokal yang selama ini menjadi pegangan dan tuntunan hidup dihilangkan begitu saja dan diganti dengan yang baru atau asing. ${ }^{16}$

Sikap diskriminatif negara terhadap penganut agama lokal memarginalisasi posisi mereka di dalam kehidupan masyarakat. Agamalokal dikategrikan sebagai kepercayaan yang tidak setara dengan agama. Bila merujuk pada definisi agama menurut Johstone yaitu seperangkat kepercayaan dan bentuk ritual dalam suatu kelompok keagamaan dalam menuntun mereka untuk mengetahu, mencari serta menjelaskan tentang dunia yang kompleks, misteri. A gama lebih lanjut dijelaskan sebagai cara mengidentifikasi tempat yang sakral untuk berlindung dalam kehidupan dunia oleh kekuasaan Tuhan yang mutlak. Pemahaman agama yang demikian tidak jauh berbeda dengan yang dimiliki oleh Ugamo Malim. Ugamo Malim sebagai agama memiliki kepercayaan kepada Tuhan dengan seperangkat nilai, aturan, ritual yang membantu mereka untuk menjalani hidupnya. Kepercayaan kepada Oppu M ula Jadi $\mathrm{Na}$ Bolon (Tuhan) memberikan mereka cara untuk selalu mengucap syukur atas berkah dan kenikmatan hidup yang mereka rasakan di dunia ini. Serangkaian ibadah mingguan juga dilakukan oleh Ugamo Malim selayaknya agama-agama lain yang ada di Indonesia. Perayaan hari besar Ugamo Malim seperti Sipaha Sada (Kelahiran raja Si Marambulubosi) dan Sipaha Lima (ritual persembahan besar) rutin dilakukan setiap tahunnya. Begitu juga dengan agama resmi lainnya yang ada di Indonesia melakukan perayaan hari besar keagamaan yang dilakukan oleh Ugamo Malim. Realitas ini membingungkan masyarakat melalui definisi negara tentang agama karena terlalu banyak persamaan yang dimiliki oleh agama lokal dengan agama resmi yang diakui pemerintah. Bentuk keadilan dan kesetaraan langkah yang lebih bijak yang dapat dilakukan oleh pemerintah kepada agama lokal. ${ }^{17}$

Peneliti pada saat dilokasi penelitian menemukan beberapa temuan bahwa identitas ssebagai Ugamo Malim memiliki makna yanag dalam bagi penganutnya.Identitas Ugamo Malim tidak lagi dianggap sesuatu yang diterima begitu saja sejak mereka lahir namun terdapat makna hidup dan bentuk perjuangan leluhur mereka. Ugamo Malim merefleksikan perbedaan identitas mereka dengan kelompok lain di masyarakat termasuk suku Batak Toba. Kebanggaan menjadi Ugamo Malim dimiliki oleh mereka karena masih mampu mempertahankan agama para leluhur

16 King, Pamela Ebstyne. 2003. Religion A nd I dentity: The R ole Of I deological, Social A nd Spiritual Context.Lawrence Erlbaum Associates.Inc.

17 Johnstone, L Ronald, Religion In A Sociology Of Religion, 2016, hlm. 15. 
Batak. Kebanggaan menjadi Ugamo Malim menjadi modal besar dalam mempertahankan eksistensi mereka di masyarakat.Keberhasilan ini tidak terlepas dari internalisasi nilai-nilai ajaran Ugamo Mal im kepada generasi mudanya sehingga tetap memiliki keinginan mempertahankan identitas yang mereka miliki. Pernyataan akan makna dan kebanggan sebagai Penaganut Ugamo Malim dapat kita lihat dalam sesi wawancara berikut ini dengan informan Ulu punguan yaitu:

“Kami ini kan dari sejak lahir sudah menjadi Ugamo malim, bahkan dari nenek saya dulu sudah jadi Parmalim terus diturunkan lagi ke mamak saya dan saya. Jadi kalau bisa dibilang Ugamo Mali mini sudah mendarah daging untuk keluarga kami. Kami juga melihat dan merasakan perjuangan dari nenek moyang kami dalam kehidupan mereka di masyarakat. Banyak dulu hambatan dan hal negatif yang di bilang orang sama kami. Akupun masih merasakan hal yang sama terutama di masa dulu yang masih agak sempit pikirannya. Kalau bisa di bilang saya Iahir menjadi U gamo Malim maka matipun nanti ya tetap Ugamo Mlaim. Tekad itu sudah ada dalam hati kita karena keimanan kita selalu hidup dalam Ugamo Malim jadi susah untuk mengoyahkan walaupun banyak cobaan di masyarakat"...

Hal senada juga disampaikan oleh informan Sirait dalam sesi wawancara dalam menjelaaskan tentang makna dan fungsi identitas Ugamo Malim dalam hidupnya yaitu:

“Kalau secara umum dilihat dalam kehidupan sehari-hari, Ugamo Malim inilah keyakinan hidup kami dan kami pegang dalam hidup. Perlu dikeetahui kalau hanya dari Ugamo Malim Iah semua permintaan dan ucapan syukur kami dapat diterima Oppu Mulajadi Na Bolon (Tuhan). Jadi ga bisa kalau agama kami itu diganti-ganti jadi agama lain karena ga bakalan sampai doadoa kami kepada Tuhan kami"...

Identitas agama telah menjaadi sesuatu yang disakralkan dan pegangan hidup bagi penganut Ugamo Malim.kedekatan secara nilai spriritual ynag mereka rasakan dalam pengalaman mereka setiap hari memberikan makna yang dalam. Pengetahuan dan pengalaman dalam hidup mereka sebagai penganut U gamo Malim memberikan rasa memiliki untuk memperjuangkan identitasnya. Realitas ini tidak lagi menganggap identitas Ugamo Malim sebagai taken for granted (diterima begitu saja) tetap sudah mengetahui makna dan fungsinya bagi mereka. Sejarah yang masih melekat dalam ingatan bersama dalam Ugamo Malim dalamp perjuangan leluhur mereka melawan Belanda dan suku sebangsanya. Ingatan bersama kembali melekat saat negara Indonesia sudah terbentuk dan mereka mengalami banyak bentuk eksklusi sosial dan diskriminasi di masyarakat. Perjuangan itu tidak lagi hanya dirasakan secara lisan tetapi mereka rasakan dalam hidup mereka sendiri. Pengakuan negara dan keinginan setara dengan agama lain menjadi tujuan kelompok yang ingin dicapai. Memahami kedalaman makna identitas Ugamo Malim di atas maka dapat meemukan suatu esensi hidup bagi diri mereka. Ugamo 
Malim bukan seperti barang yang dapat diganti dan ditukar begitu saja. Justru melalui Ugamo Malim mereka dapat merasakan arti dan makna hidupnya. Keberadaan Ugamo Malim dapat menjadi ruang diskusi baru bagi kita dalam memahamai definisi agama yang sudah ditentukan negara. Negara mebentuk definisi agama yang cenderung mengesklusi hak dan kebebasan kelompok minoritas tertentu di masyarakat. Keadilan salah satu pokok kunci didirikannya negara Indonesia karena keadilan bukan hanya milik mayoritas tetapi meiliki bersama oleh seluruh rakyat Indonesia.

\section{REKONSTRUKSI IDENTITAS UGAMO MALIN}

Keberadaaan agama lokal menjadi wujud dari bertahannya tradisi yang telah ada di bumi nusantara sejak dari dulu. A gama lokal memiliki caranya masing-masing untuk tetap bertahan dan mempertahankan eksistensinya masing-masing. Terdapat dua bentuk cara yang dilakukan oleh agama lokal dalam mempertahankan eksistensinyaa. Pertama, agama lokal cenderung tertutup, konservatif dan menolak kehidupan modernitas sehingga berada pada derah yang terisolasi. Kedua, agama lokal telah memiliki sifat terbuka, berbaur dengan masyarakat dan menerima kehidupan modernitas. Pada agama lokal yang cenderung tertutup terdapat dalam penelitian dari Hafid dimana agama lokal Kajang menolak dan menjauhkan diri dari modernitas karena dianggap dapat merusak sistem adat dan tradisionalitas mereka. Realitas berbeda justru di tunjukkan oleh Ugamo Malim yang sejak lama sudah tinggal bersama dengan agama lain dan berusaha untuk diterima di masyarakat. Pengalaman kedua kelompok agama lokal tadi justru yang menentukan langkah mereka agar dapat mempertahankan eksistensinya. Pada agama lokal Kajang masih memungkinkan untuk menolak modernitas dan tertutup karena wilayah terisolasi dan otonom. Sedangkan Ugamo Malim sudah tidak memungkinkan melakukan hal itu karena memiliki ketergantungan yang besar kepada masyarakat lain maupun negara. Dengan demikian penerimaan terhadap nilai modernitas dan perubahan identitas lebih mudah dilakukan dalam kelompok U gamo M alim. A pabila tetap mempertahankan sifat tertutup dan menolak modernitas maka sulit sekali memenuhi kebutuhan dasar mereka di dalam kehidupannya seharihari. ${ }^{18}$

Proses terjadinya perubahan identitas Ugamo Malim tidak terlepas dari kenyataan yang dihadapi dalam berhadapan dengan negara dan

18 Hafid, A bdul, Belief System In Indigineous Community Of Kajang In TheV illage O f T anah Towa, District Of Kajang, Regency Of Bulukumba. Balai Pelestarian Nilai Budaya Makassar, Kementerian Pendidikan Dan Kebudayaan, 2016, hlm. 9. 
kel ompok agama mayoritas lainnya. Bentuk identitas yang mereka miliki di masa lalu cenderung konservatif, tradisional dan kurang terbuka terhadap kehidupan modernitas. Naumun, seiring perkeembangan waktu banyak hambatan dan keterbatasan ekspresi yang mereka hadapi terutama melalui beragam perbedaan atribut identitas yang mereka miliki. Identitas yang terlalu menonjolkan sifat tertutup dan pemakaian baju tradisional justru menghambat mereka diterima di masyarakat. Hal ini dilatarbelakangi bahwa mereka yang tradisional memiliki hubungan dekat dengan kehidupan mistis dan alam gaib. Dengan demikian ada keenggenan dari masyarakat untuk menerima atau bergaul dengan mereka. Sebagaiaman halnya anggapan Umum di Indonesia maka agama lokal masih dianggap sebagai penganut animisme, tak bertuhan dan aliran sesat. Pelabelan negatif demikian mendorong secara naluriah bagi setiap individu di masyarakat untuk melakukan diskriminasi. Begitu juga negara yang sebelumnya juga belum mengakui keberadaan agama lokal sehingga dikategorikan sebagai aliran kepercayaan. Pengkategorian negara terhadap agama lokal sebagai kepercayaan melanggengkan stigma negatif masyarakat terhadap mereka. Negara sebagai salah satu yang memberikan keabsahan hukum dan menentukan kebenaran yang legitimate (legitimasi) memperburuk keadaan agama lokal. Agama mayoritas atas nama kenyamanan publik dan syiar agama maka dapat melakukan persekusi maupun tindakan kekerasan pada agama lokal. Keadaan ini berdampak signifikan akibat tidak adanya perlindungan hukum dari negara keada agama lokal.

Kebutuhan akan perubahan dan kondisi dinamika bernegara dan kehidupan di masyarakat mendorong Ugamo Malim melakukan perubahan pada identitas yang mereka miliki. Perubahan dapat terlihat pada konsepsi mereka tentang Tuhan yang mereka miliki. Di Indonesia konsep beragama selalu diasosiasikan dengan Tuhan yang tunggal. Masyarakat yang memiliki Tuhan tunggal dianggap memiliki nilai religiusitas yang baik dan sakral. Beberapa agama mayoritas di Indone sia memakai konsep teologis demikian dalam kehidupan beragamanya di masyarakat maupun negara. Realitas yang sama juga dapat kita temukan pada Ugamo Malim yang menggunakan konsep ketuhanan Tunggal yaitu $\mathrm{O}$ ppu M ula Jadi $\mathrm{N}$ a Bol on ${ }^{19}$ (Tuhan). Setiap orang yang hidup maupun pernah bergaul bersama dengan Ugamo Malim pasti mereka selalu menyatakan hal yang sama. Mereka secara tegas menyatakan memiliki banyak kesamaan dengan agama mayoritas lainnya di Indonesia. Hal ini membantah anggapan bahwa agama lokal di Indonesia sebagai penganut animisme karena terbukti mereka tidak pernah memuja

19 Oppu M ulajadi Na Bolon merupakan Tuhan yang dipercaya dan disembah oleh penganut Ugamo Malim sehingga memiliki persamaan dengan agama mayoritas di Indonesia. 
roh nenek moyang mereka tetapi meneyembah Tuhan yang mereka percayai. A pabila melihat agama lokal masih melakukan sesajen maka itu dianggap sebagai ucapan syukur kepada Tuhan yang telah memberikan berkah dan kenikmatan hidup di dunia. Secara sadar atau tidak sadar sebenarnya U gamo Malim berusaha untuk menyesuaikan konsep ketuhanan yang ditentukan oleh negara sehingga dapat diakui nantinya di masa depan.

Dalam pergaulan hidup Ugamo Malimm juga melakukan rekonstruksi idnetitasnya di masyarakat agar dapat diterima dengan baik. Batas perbedaan antara penganut Ugamo Malim dengan penganut agama mayoritas sudah tidak terlihat lagi dalam kehidupan sehariharinya. Realitas ini ditunjukkan dalam cara mereka bersikap maupun cara praktik hidup yang dilakukan dalam kehidupan sehari. Penganut Ugamo Malim begitu terbuka terhadap kehidupan modern, perangkat teknologi, pendidikan tinggi dan penggunaan media sosial. Pada suatu kesempatan pernah ada beberapa orang luar datang ke lokasi peneitian untuk meminta sumbangan untuk panti asuhan yang beragama Islam. Namun, orang meminta sumbangan itu justru tidak bisa membedakan rumah yang meeka kunjungi masih penganut Ugamo Malim. Begitu juga apabila ada hajatan pesta di desa itu maka sulit sekali bagi orang luar untuk mengidentifikasi Ugamo Malim dengan penganut lainnya karena pakaiannya tetap sama.Kemampuan Ugamo Malim yang begitu cepat untuk melebur dengan kehidupan modern mempermudah mereka diterima di masyarakat. Jarak sosial yang selama ini terbnetuk karena perbedaan yang mencolok baik secara pakaian, sikap hidup dan nilai yang dianut secara umum telah berkurang. A da kecenderungan penganut agama Islam di desa itu lebih dekat dengan Ugamo Malim karena kesamaan nilai keagamaan berupa tidak memakan makanan haram. Cara Ugamo Malim dalam menghadapi masalah juga cenderung tenang dan moderat dibandingkan Batak yang beragama lain sehingga memberikan kenyamanan bersosialisasi di masyarakat.

Bentuk rekonstruksi lain yang dimiliki oleh Ugamo Malim dilakukan melalui pendidiakn formal. Persaingan terhadap sumberdaya manusia mennjai salah satu syarat agar mereka tetap dapat memeprtahankan eksisitensinya di masyarakat. Pendidikan formal bukan sesuatu yang baru bagi Ugamo Malim. Pada masa penjajahan Belanda, Ugamo Malim pernah memiliki kemajuan pendidikan di masanya dalam mengimbangi sekolah Z ending Kristen di masa itu. Parmalim School dibentu dan diinisiasi oleh pemimpin Ugamo Malim agar mereka dapat mengimbangi Krsiten yang sudah maju dalam ilmu pengetahuan. Walaupun pada akhirnya Parmalim school harus dibubarkan oleh Belanda karena di anggap dapat mengancam keberadaan kekuasaan Belanda. Begitu juga dengan guru dan beberapa muridnya yang berpotensi ditangkap dan diasingkan 
kedaerah yang jauh. Ingatan tentang Parmalim school itu masih melekat kuat dalam diri setiap Ugamo Malim sehingga kepedulian terhadap pendidikan menjadi modal utama bagi mereka. Sebelum pelajaran U gamo Malim diperbolehkan masuk di tahun 2018 oleh peraturan menteri kebudayaan dan pendidikan maka Ugamo Malim telah lama melakukan advokasi kebutuhan pendidikan bagi diri mereka. Perjuangan itu akhirnya dikabulkan dan mereka sekarang dapat belajar Ugamo Malim di sekolah tanpa harus di paksa belajar agama lain. Beberapa generasi muda Ugamo Malim cukup aktif dalam dunia pendidikan sehingga telah banyak yang Iulus sarjana, dokter maupun kuliah magister.

Pendekatan Iain juga dilakukan oleh Ugamo Malim dalam merkonstruksi identitasnya di masyarakat. Situasi yang dinamis membentuk cara tersendiri bagi Ugamo Malim dalam merekonstruksi identitasnya dengan kelompok agama lain. Relasi hubungan yang baik dibentuk melalui persamaan nilai tertentu antara Ugamo Malim dengan agama lainnya. Pada agama Batak Kristen ada kecenderungan suatu ikatan keluarga dan adat sehingga sering dipertemukan dal am acara adat seperti pernikahan, meninggal dan acara adat lainnya. Secara adat baik Batak Kristen maupun Ugamo Malim wajib hadir dalam hajatan pesta karena telah memiliki status dan peran masing-masing dalam adat. Penghormatan terhadap aturan adat masih kuat dalam suku Batak sehingga menyatukan perbedaan yang ada. Pertemuan dan dialog langsung justru memberikan suatu pengetahuan baru tentang keberadaan Ugamo Malim. Bentuk toleransi dan tenggang rasa juga biasanya tercermin dalam acara adat suku Batak. Terkadang ada beberapa kondisi dimana Ugamo Malim harus menerima jambar (hak untuk menerima potongan daging sesuai posisi di adat) berupa daging babi (haram bagi Ugamo Malim). Situasi ini justru tidak menyurutkan Ugamo Malim datang ke acara pesta adat tetapi lebih meningkatkan sifat tenggang rasa dan toleransi. Namun, beberapa suku Batak Kristen sudah mengerti kondisi ini maka disediakan jambar (daging kambing atau kerbau) sehingga dapat diterima oleh Ugamo Malim. Keterikatan secara adat inilah yang memberikan suatu rasa aman (security) bagi Ugamo Malim di tanah batak. Prinsip dalam suku Batak bahwa kalau masih terikat dalam ikatan adat dan satu darah maka sulit bagi suku lain untuk melakukan persekusi pada Ugamo Malim.

Pendekatan kepada agama Islam justru ditarik dari kesamaan kultur nilai agama yang sama antara Ugamo Malim dengan Islam. Pada Ugamo Malim sangat dilarang untuk memelihara babi, anjing dan hewan haram lainnya. Hewan ini juga tidak boleh dikonsumsi sebagai makanan karena melanggar nilai agama. Kesamaan nilai ini membuat penganut agama Islam merasa nyaman untuk bertetangga dan mau makan di rumah Ugamo Malim. Secara umum juga Ugamo Malim cenderung memiliki 
sifat pembersih dalam kehidupan sehari-harinya. $\mathrm{H}$ al ini dilatarbelakangi dari cerminan nilai Ugamo Malim karena mereka akan lebih diterima saat hidupnya bersih. Keyakinan Ugamo Malim mengakui bahwa Tuhan lebih menerima yang dapat hidup bersih secara fisik maupun bekerja secara halal (bersih). Berbeda dengan anggapan umum tentang Batak Krsiten yang dalam beberapa orang kurang memiliki rasa estetika dan hidup bersih. Dengan demikian Ugamo Malim telah memberikan kenyamanan bertetangga dengan penganut agama Islam sehingga dapat berdampingan hidup di masyarakat. Kenyamanan ini menjadi bentuk rekonstruksi identitas yang dimiliki oleh Ugamo Malim dalam masyarakat.

\section{PEN UTUP}

Konstruksi negara terhadap definisi agama telah membentuk fragmentasi di masyarakat yang menimbulkan dampak negatif. Negara pada awal kemerdekaan telah membentuk defenisi agama akibat dari tuntutan politik dari kelompok tertentu melihat perkembangan agama lokal di masa itu. Perkembangan agama lokal sampai pada tahun 1965 telah mencapai 360an kelompok agama lokal sehingga dapat mempengaruhi publik secara nasional. M elalui definisi agama oleh negara maka secara perlahan posisi agama lokal mulai dimarginalisasi. Agama lokal dilabelkan sebagai kelompok tak berTuhan, aliran sesat dan dianggap meresahkan masyarakat lain. Peran negara tidak lagi hanya sekedar mendefinisikan agama tetapi mulai membentuk lembaga Pengawas Aliran Kepercayaan dan Aliran Keagamaan Dalam Masyarakat (PA KE M ). Kebebasan penganut agama lokal mulai dikekang dengan seperangkat aturan yang diterapkan oleh PA KEM bagi mereka. Puncaknya terjadi di masa orde lama saat negara memaksa penganut agama lokal harus memiliki agama untuk menjadi warga negara di Indonesia.

Pengakategorian agama lokal sebagai aliran kepercayaan mengharuskan mereka untuk memilih salah satu agama resmi yang ada di Indonesia. Beberapa agama lokal merasakan dampak kebijakan ini seperti agama lokal Towani Tolotang, kejawen, Wetu Telu, Kaharingan harus memilih agama resmi. Identitas mereka sebagai agama lokal perlahan hilang dan tergantikan dengan identitas baru. Namun, keinginan untuk kembali pada ajaran agama lokal terdahulu tetap ada karena agama dalam masyarakat Indonesia bukan dimaknai sebagai simbol saja. Pada masyarakat Indonesia agama dianggap sebagai sesuatu yang memiliki kedalaman makna dan tuntunan hidup (way of life). A gama juga menjadi anchor (jangkar) yang meletakkan sikap dan pedirian individu di dalam bermasyarakat. Menariknya syarat minimal yang ditentukan oleh negara sebagai agama sudah terasa kabur bagi agama lokal. Dalam konteks 
sekarang seluruh syarat minimal yang ditentukan negara sebagai agama sudah dapat dipeuhi oleh agama lokal sehingga perlu kajian ulang terhadap defenisi agama oleh negara. Pengakuan negara terhadap agama lokal melalui Mahkamah Konstitusi suatu kemajuan besar bagi lokal karena hak mereka sudah diakui. Perjuangan ini belum berakhir bagi agama lokal sebab belum mencapai kesetaraan antara agama lokal dengan agama resmi.

Eksistensi agama lokal di Indonesia mengalami dinamika yang sangat panjang dalam kehidupan masyarakat maupun negara di Indonesia. Pasang surut keberadaan agama lokal pernah dirasakan agama lokal dan berimplikasi dengan relasinya dengan negara. N egara dan masyarakat mayoritas turut ikt andil dalam menghambat eksistensi agama lokal di Indonesia sehingga terjadi penurunan jumlah penganut agama lokal. Pada masa itu identitas agama lokal dianggap tidak relevan dengan kehidupan modernitas karena bertentangan dengan nilai agama mayoritas maupun negara. Negara pada beberapa insiden melakukan pembubaran pada agama loka karena dianggap melanggar aturan negara. Secara perlahan agama lokal di Indonesia sudah mulai dapat beradaptasi dan melakukan perjuangan melalui jalur hukum. Perjuangan agar diakui negara sudah dilakukan melalui keputusan Mahkamah Konstitusi sehingga telah ditetapkan dalam kebijakan negara. Identitas agama lokal baik secara teologis juga sudah menyesuaikan dengan ketentuan negara karena telah menganut konsep Tuhan tunggal. Dalam pergaulan di masyarakat penganut agama lokal melakukan langkah efektif dengan meanrik persamaan dengan agama mayoritas. Kehidupan sehari-hari agama lokal telah memiliki banyak kesamaan dan hampir tidak bisa dibedakan dengan agama lainnya. Konstruksi agama lokal sebagai tak bertuhan, kolot, primitif dan tertutup telah dapat dibantah dengan rekonstruksi identitas baru yang mereka miliki.

* Wensdy Tindaon

M ahasiswa Program Pascasarjana sosiologi, U niversitas Indonesia. Email: sitindaonwensdy@ gmail.com

\section{BIBLIOG RAFI}

Aryono. 2018. Pergulatan aliran kepercayaan dalam panggung politik Indonesia, 1950an-2010an: romo semono sastrodihardjo dan aliran kapribaden. Jurnal sejarah citra lekha.

Adams, M Kathleen. 1993. The Discourse of Souls Ia Tana Toraja (Indonesia): Indigineous $\mathrm{N}$ otions And Christian Conception. University Pitsburgh. 
Hasse, J. 2010. Kebijakan N egara Terhadap A gama Lokal Towani Tolotang di Kabupaten Sidrep, Sulawesi Selatan. Jurnal Studi Pemerintahan.

Harahap, Irwansyah. 2000. Rasionalisasi Religius Dalam Diskursus Keagamaan Di Indonesia Parmalim Batak Toba. Antropologi Indonesia.

Hirosue, Masashi 1988. Prophets Anda Follower In Batak M illennerian Responses To The Colonial Order: Parmalim In Nasiak Bagi Anda Parhudamdam 1890-1930. Australian National University, Canberra.

Johnstone, L Ronald. 2016. Religion In A Sociology Of Religion. Routledge Khotimah. 2014. A gama dan civil society. Jurnal usluhuddin

King, Pamela Ebstyne. 2003. Religion A nd Identity: The Role Of Ideological, Social And Spiritual Context. Lawrence Erlbaum Associates.Inc.

Mustajab, Ali. 2015. Kebijakan Politik Gusdur Terhadap China Tionghoa Di Indonesia. Jurnal Agama Dan Hak Azasi Manusia.

Sukamto, Amos. 2013. Ketegangan A ntar Kelompok A gama Pada M asa O rde Lama Sampai A wal O rde Baru: D ari Konflik Perumusan Ideology N egara Sampai K onflik Fisik. Interuniversity Institute Of Ecumenical And Misiological. 